\title{
Front Matter: Volume 10955
}

, "Front Matter: Volume 10955," Proc. SPIE 10955, Medical Imaging 2019: Ultrasonic Imaging and Tomography, 1095501 (21 May 2019); doi: $10.1117 / 12.2533486$

SPIE. Event: SPIE Medical Imaging, 2019, San Diego, California, United States 


\title{
PROGRESS IN BIOMEDICAL OPTICS AND IMAGING
}

\section{Medical Imaging 2019}

\section{Ultrasonic Imaging and Tomography}

\author{
Brett C. Byram \\ Nicole V. Ruiter \\ Editors
}

17-18 February 2019

San Diego, California, United States

Sponsored by

SPIE

Cooperating Organizations

AAPM-American Association of Physicists in Medicine (United States)

IFCARS - International Foundation for Computer Assisted Radiology and Surgery (Germany)

MIPS-Medical Image Perception Society (United States)

SIIM-Society for Imaging Informatics in Medicine (United States)

WMIS—World Molecular Imaging Society

Published by

SPIE

Volume 10955 
The papers in this volume were part of the technical conference cited on the cover and title page. Papers were selected and subject to review by the editors and conference program committee. Some conference presentations may not be available for publication. Additional papers and presentation recordings may be available online in the SPIE Digital Library at SPIEDigitallibrary.org.

The papers reflect the work and thoughts of the authors and are published herein as submitted. The publisher is not responsible for the validity of the information or for any outcomes resulting from reliance thereon.

Please use the following format to cite material from these proceedings:

Author(s), "Title of Paper," in Medical Imaging 2019: Ultrasonic Imaging and Tomography, edited by Brett C. Byram, Nicole V. Ruiter, Proceedings of SPIE Vol. 10955 (SPIE, Bellingham, WA, 2019) Sevendigit Article CID Number.

ISSN: 1605-7422

ISSN: $2410-9045$ (electronic)

ISBN: 9781510625570

ISBN: 9781510625587 (electronic)

Published by

SPIE

P.O. Box 10, Bellingham, Washington 98227-0010 USA

Telephone +1 3606763290 (Pacific Time) · Fax +1 3606471445

SPIE.org

Copyright @ 2019, Society of Photo-Optical Instrumentation Engineers.

Copying of material in this book for internal or personal use, or for the internal or personal use of specific clients, beyond the fair use provisions granted by the U.S. Copyright Law is authorized by SPIE subject to payment of copying fees. The Transactional Reporting Service base fee for this volume is $\$ 18.00$ per article (or portion thereof), which should be paid directly to the Copyright Clearance Center (CCC), 222 Rosewood Drive, Danvers, MA 01923. Payment may also be made electronically through CCC Online at copyright.com. Other copying for republication, resale, advertising or promotion, or any form of systematic or multiple reproduction of any material in this book is prohibited except with permission in writing from the publisher. The CCC fee code is 1605$7422 / 19 / \$ 18.00$.

Printed in the United States of America by Curran Associates, Inc., under license from SPIE.

Publication of record for individual papers is online in the SPIE Digital Library.

\section{SPIE. DIGITAL}

Paper Numbering: Proceedings of SPIE follow an e-First publication model. A unique citation identifier (CID) number is assigned to each article at the time of publication. Utilization of CIDs allows articles to be fully citable as soon as they are published online, and connects the same identifier to all online and print versions of the publication. SPIE uses a seven-digit CID article numbering system structured as follows:

- The first five digits correspond to the SPIE volume number.

- The last two digits indicate publication order within the volume using a Base 36 numbering system employing both numerals and letters. These two-number sets start with 00, 01, 02, 03, 04, 05, 06, 07, 08, 09, OA, OB ... 0Z, followed by 10-1Z, 20-2Z, etc. The CID Number appears on each page of the manuscript. 


\title{
Contents
}

\author{
vii Authors \\ ix Conference Committee \\ xi 2019 Medical Imaging Award Recipients
}

\section{SESSION 1 BLOOD FLOW}

1095502 Deep 3D convolutional neural networks for fast super-resolution ultrasound imaging [10955-1]

1095503 Independent component analysis-based tissue clutter filtering for plane wave perfusion ultrasound imaging [10955-2]

1095504 Accuracy improvement of echographic speckle tracking based on analysis of estimation error caused by acoustic pressure field [10955-3]

109505 Morphological image processing for multiscale analysis of super-resolution ultrasound images of tissue microvascular networks [10955-4]

1095506 A two-fold enhancement of ultrasound vessel images using a non-local based restoration and morphological filtering [10955-5]

SESSION 2 US TOMOGRAPHY I

1095508 Open-source Gauss-Newton-based methods for refraction-corrected ultrasound computed tomography [10955-7]

$1095509 \quad$ Employing methods with generalized singular value decomposition for regularization in ultrasound tomography [10955-8]

10955 OA Full waveform inversion for ultrasound computed tomography with high-sensitivity scan method [10955-9]

10955 OB Accelerating image reconstruction in ultrasound transmission tomography using L-BFGS algorithm [10955-10]

10955 OC Correlation of ultrasound tomography to MRI and pathology for the detection of prostate cancer [10955-24] 
10955 OD On the feasibility of quantifying mechanical anisotropy in transversely isotropic elastic materials using acoustic radiation force (ARF)-induced displacements [10955-12]

10955 OE Axially-segmented cylindrical array for intravascular shear wave imaging [10955-13]

$10955 \mathrm{OF} \quad$ Classification of cardiac adipose tissue using spectral analysis of ultrasound radiofrequency backscatter [10955-14]

$109550 \mathrm{G}$ Tracking blood flow changes in the brains of neonates using angular-coherence-based power doppler [10955-15]

$10955 \mathrm{OH} \quad$ An adaptive coherent flow power doppler beamforming scheme for improved sensitivity towards blood signal energy [10955-16]

SESSION 4 US TOMOGRAPHY II

10955 Ol High SNR emission method with virtual point source in ultrasound computed tomography [10955-23]

10955 0J Experimental analysis of ray-based sound speed reconstruction algorithms for phase aberration corrected USCT SAFT imaging [10955-1 1]

$10955 \mathrm{OL} \quad$ A high throughout, extensible and flexible ultrasonic excitation and acquisition system for ultrasound imaging [10955-26]

$10955 \mathrm{ON}$ Study on acceleration schemes in Fresnel volume tomography for sound speed reconstruction [10955-40]

\section{SESSION 5 BEAMFORMING AND IMAGE FORMATION}

1095500 Coherent multi-transducer ultrasound imaging in the presence of aberration [10955-17]

10955 OP High dynamic range ultrasound beamforming using deep neural networks [10955-19]

10955 OQ Row-column beamforming with dynamic apodizations on a GPU [10955-20]

10955 OR Estimating signal and structured noise in ultrasound data using prediction-error filters [10955-21]

10955 OS The impact of mid lag spatial coherence parameters on coherent target detection [10955-22] 
10955 OT Left ventricular ejection fraction assessment: unraveling the bias between area- and volume-based estimates [10955-28]

10955 OU 3D ultrasound biomicroscopy (3D-UBM) imaging and automated 3D assessment of the iridocorneal angle for glaucoma patients [10955-29]

10955 OV Ultrasound prostate segmentation based on 3D V-Net with deep supervision [10955-30]

10955 OW Ultrasound-guided breast biopsy of ultrasound occult lesions using multimodality image co-registration and tissue displacement tracking [10955-45]

10955 0X Three-dimensional color Doppler ultrasound simulation to mimic paravalvular regurgitation [10955-32]

10955 OY Deep learning techniques for bone surface delineation in ultrasound [10955-33]

\section{SESSION 7 KEYNOTE AND NEW APPLICATIONS}

$109512 \quad$ Ultrasound backscattered tensor imaging of the brain: an ex vivo feasibility study [10955-37]

$109513 \quad$ Electroacoustic tomography (EAT): linear scanning with a single element transducer [10955-38]

\section{POSTER SESSION}

$109514 \quad$ Automatic recognition processing in ultrasound computed tomography of bone [10955-39]

109515 Adaptive truncated total least square on distorted born iterative method in ultrasound inverse scattering problem [10955-41]

109516 Deep learning image reconstruction method for limited-angle ultrasound tomography in prostate cancer (Cum Laude Poster Award) [10955-42]

109517 Image retrieval of breast masses on ultrasound images [10955-43]

109518 Improvement in transmission ultrasound tomography by refined dynamic programming and spatial filter [10955-44]

10955 1 A Developing a quantitative ultrasound image feature analysis scheme to assess tumor treatment efficacy using a mouse model [10955-47]

10955 1B Electroacoustic tomography system with nanosecond electric pulse excitation source [10955-49] 
$109551 \mathrm{C}$ Neighborhood resonance phenomenon for cell imaging via scanning probe acoustic microscope [10955-50]

10955 1D Deep 3D convolutional neural network for automatic cancer tissue detection using multispectral photoacoustic imaging [10955-51] 


\section{Authors}

Numbers in the index correspond to the last two digits of the seven-digit citation identifier (CID) article numbering system used in Proceedings of SPIE. The first five digits reflect the volume number. Base 36 numbering is employed for the last two digits and indicates the order of articles within the volume. Numbers start with 00, 01, 02, 03, 04, 05, 06, 07, 08, 09, OA, OB...0Z, followed by 10-12, 20-2Z, etc.

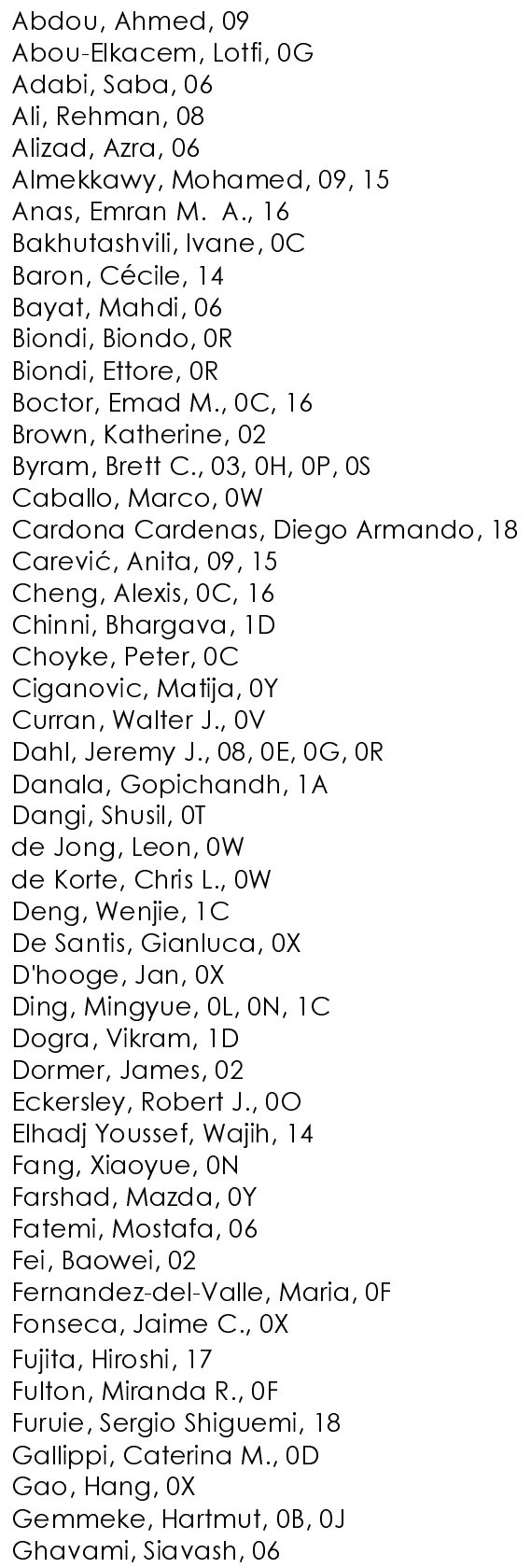

Givan, Amy H., OF

Göksel, Orcun, OY

Gomez, Alberto, 00

Groenhuis, Vincent, oW

Guillermin, Régine, 14

Hajnal, Joseph $V_{\text {., }} 00$

Hansen, Hendrik H. G., OW

$\mathrm{He}$, Xiuxiu, OV

Heidari, Morteza, 1 A

Helms, Rich, OU

Herickhoff, Carl D., OE

Hesser, Jürgen, OB

Higuchi, Shunichi, 17

Hopp, Torsten, OB, OJ

Hossain, Md Murad, OD

Hoyt, Kenneth, 02, 05

Hsi, Ryan, OS

Hsieh, Scott, 08

Jakovljevic, Marko, OG, OR

Jani, Ashesh B., OV

Jennings, Joseph, OR

Jensen, Jørgen Arendt, $O Q$

Jnawali, Kamal, 1D

Jones, Rebecca, OS

Karlapalem, Akhila, OF

Kato, Fumi, Ol

Kawabata, Kenichi, OA, OI

Kawasaki, Tomonori, 17

Kim, Younsu, 16

Kishimoto, Shun, OC

Klingensmith, Jon D., OF

Krishna, Murali C., OC

Lasaygues, Philippe, 14

Lei, Yang, OV

Lenox, Mark, OC

Li, Si Jia, 12

$\mathrm{Li}$, Xiaoging, $1 \mathrm{C}$

Linte, Cristian A., OT

Liu, Dawei, OT

Liu, Tian, OV

Luchies, Adam, OP

Machhout, Mohsen, 14

Malik, Bilal, OC

Mann, Ritse, OW

Mao, Hui, OV

Maris, Bogdan, OW

Marwa, Fradi, 14

Merino, Maria, OC

Merrill, John A., 13, 1B 
Minhaz, Ahmed Tahseen, OU

Mirniaharikandehei, Seyedehnafiseh, 1 A

Morita, Takako, 17

Mousavi, Parvin, 12

Munasinghe, Jeeva, OC

Muramatsu, Chisako, 17

Negussie, Ayele H., OC

Nikolaev, Anton, OW

Nishida, Mutsumi, Ol

Oiwa, Mikinao, 17

Okada, Takashi, 04

Orge, Faruk, ou

Özdemir, Firat, OY

Özdemir, lpek, 05

Ozgun, Kathryn A., $\mathrm{OH}$

Papachristidis, Alexandros, OX

Patel, Pretesh, OV

Peck, Isabelle, OT

Peng, Yang, OL, ON

Peralta, Laura, 00

Petit, Philippe, 14

Pinto, Peter, 0C

Quan, Zhaohui, ON

Queirós, Sandro, OX

Rahmim, Arman, OC, 16

Ranjan, Ashish, 1A

Rao, Navalgund, 1D

Rubesova, Erika, OG

Ruiter, N.V., OJ

Satoh, Megumi, Ol

Schlunk, Siegfried, OS

Schou, Mikkel, $0 Q$

Schwarz, Karl Q., OT

Sechopoulos, loannis, OW

Seifabadi, Reza, 0C, 16

Sevgi, Duriye Damla, ou

Shimizu, Motochika, 04

Siepel, Françoise, OW

Sinha, Saugata, 1D

Slapničar, Ivan, 09

Song, Junjie, OL, ON

Stuart, Matthias Bo, $\mathrm{OQ}$

Sun, Xia, OL

Suzuki, Atsuro, OA, Ol

Tagliabue, Eleonora, OW

Tanaka, Tomohiko, 04

Telichko, Arsenii V., OE

Terada, Takahide, OA, OI

Tian, Sibo, OV

Tierney, Jaime E., 03, OS

Tsubota, Yushi, OA, Ol

Turkbey, Baris, OC

VanOsdol, Joshua, 1A

Vilaça, João L., OX

Wang, Bo, OV

Wang, Hongjian, $\mathrm{OB}$

Wang, Mengxiao, 13

Wang, Shanshan, OL

Wang, Siqi, 13, 1B

Wang, Tonghe, OV
White, Phillip Jason, 12

Wilkes, Don M., 03

Wilson, David L., OU

Wiskin, James, OC

Wood, Bradford J., OC, 16

Wu, Hao, OU

Wu, Wenjing, OA, OI

Wu, Yun, ON

Xiang, Liangzhong, 13, 1B

Yamanaka, Kazuhiro, OA, OI

Yamashita, Hiroko, $\mathrm{Ol}$

Yang, Xia ofeng, OV

Yoon, Byung Jason, OG

Yu, Taocheng, OU

Yuchi, Ming, OL, ON

Yun, Xingzhao, 15

Zapf, M., OJ

Zarafshani, Ali, 13, 1B

Zhang, Qiude, OL, ON

Zheng, Bin, 13, 1A, 1B

Zhou, Liang, OL, ON

Zhou, Quan, OL, ON

Zuch, F., OJ 


\section{Conference Committee}

Symposium Chairs

Ronald M. Summers, National Institutes of Health Clinical Center

(United States)

Georgia D. Tourassi, Oak Ridge National Laboratory (United States)

Conference Chairs

Brett C. Byram, Vanderbilt University (United States)

Nicole V. Ruiter, Karlsruher Institut für Technologie (Germany)

Conference Program Committee

Mark A. Anastasio, Washington University in St. Louis (United States)

Jeffrey C. Bamber, The Royal Marsden NHS Foundation Trust

(United Kingdom)

Johan G. Bosch, Erasmus University Rotterdam (Netherlands)

Jan D'hooge, Universitair Ziekenhuis Leuven (Belgium)

Marvin M. Doyley, University of Rochester (United States)

Neb Duric, Delphinus Medical Technologies, Inc. (United States)

Stanislav Y. Emelianov, The University of Texas at Austin (United States)

Mostafa Fatemi, Mayo Clinic College of Medicine (United States)

Aaron Fenster, Robarts Research Institute (Canada)

Jérémie Fromageau, The Institute of Cancer Research

(United Kingdom)

James F. Greenleaf, Mayo Clinic (United States)

Emma J. Harris, The Institute of Cancer Research (United Kingdom)

Michael Jaeger, Universität Bern (Switzerland)

Jørgen Arendt Jensen, Technical University of Denmark (Denmark)

David H. Kim, Pohang University of Science and Technology

(Korea, Republic of)

Roman G. Maev, University of Windsor (Canada)

Bilal H. Malik, QT Ultrasound LLC (United States)

Stephen A. McAleavey, University of Rochester (United States)

Mohammad Mehrmohammadi, Wayne State University

(United States)

Svetoslav I. Nikolov, BK Medical (Denmark)

Olivier Roy, Barbara Ann Karmanos Cancer Institute (United States)

Kai E. Thomenius, Massachusetts Institute of Technology

(United States)

François Varray, CREATIS (France)

James W. Wiskin, QT Ultrasound LLC (United States) 


\section{Session Chairs}

1 Blood Flow

Marko Jakovljevic, Stanford University School of Medicine (United States) Jørgen Arendt Jensen, Technical University of Denmark (Denmark)

2 US Tomography I

Torsten Hopp, Karlsruher Institut für Technologie (Germany)

James W. Wiskin, QT Ultrasound LLC (United States)

3 Elastography, Tissue Classification and Doppler

Brett C. Byram, Vanderbilt University (United States)

Arsenii Telichko, Stanford University School of Medicine (United States)

4 US Tomography II

Mohamed Almekkawy, The Pennsylvania State University (United States)

Neb Duric, Delphinus Medical Technologies, Inc. (United States)

5 Beamforming and Image Formation

Adam C. Luchies, Vanderbilt University (United States)

Bilal H. Malik, QT Ultrasound LLC (United States)

$6 \quad$ Image Processing and Analysis

Kenneth L. Hoyt, The University of Texas at Dallas (United States)

$7 \quad$ Keynote and New Applications

Nicole V. Ruiter, Karlsruher Institut für Technologie (Germany)

Neb Duric, Delphinus Medical Technologies, Inc. (United States) 


\section{Medical Imaging Award Recipients}

\section{Robert F. Wagner Best Student Paper Award}

Robert F. Wagner was an active scientist in the SPIE Medical Imaging meeting, starting with the first meeting in 1972 and continuing throughout his career. He ensured that the BRH, and subsequently the $\mathrm{CDRH}$, was a sponsor for the early and subsequent Medical Imaging meetings, helping to launch and ensure the historical success of the meeting. The Robert F. Wagner All-Conference Best Student Paper Award (established 2014) is acknowledgment of his many important contributions to the Medical Imaging meeting and his many important advances to the field of medical imaging.

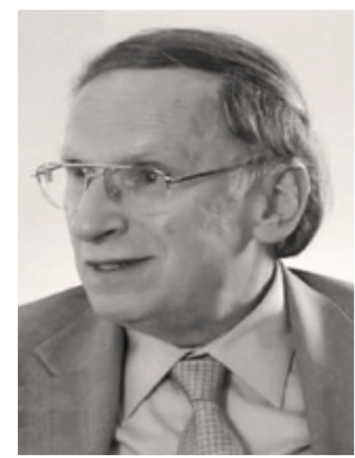

This award is co-sponsored by:

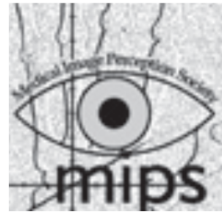

The Medical Image Perception Society

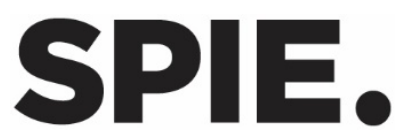

\section{Recipients:}

First Place: Volume-of-interest imaging using multiple aperture devices (10984-74) Wenying Wang, Grace J. Gang, Jeffrey H. Siewerdsen, Joseph W. Stayman, Johns Hopkins University (United States)

Second Place: Surgical aid visualization system for glioblastoma fumor identification based on deep learning and in-vivo hyperspectral images of human patients (10951-35)

Himar Fabelo, The University of Texas at Dallas (USA) and Universidad of Las Palmas de Gran Canaria (Spain); Martin Halicek, The University of Texas at Dallas (United States) and Georgia Institute of Technology \& Emory University School of Medicine (United States); Samuel Ortega, Universidad de Las Palmas de Gran Canaria (Spain); Adam Szolna, Jesus Morera, Hospital Universidad de Gran Canaria Doctor Negrin (Spain); Roberto Sarmiento, Universidad of Las Palmas de Gran Canaria (Spain); Gustavo M. Callicó, Universidad de Las Palmas de Gran Canaria (Spain); Baowei Fei, The University of Texas at Dallas (United States) and The University of Texas Southwestern Medical Center (United States) 
Proc. of SPIE Vol. 10955 1095501-12 Downloaded From: https://www.spiedigitallibrary.org/conference-proceedings-of-spie on 26 Apr 2023
Terms of Use: https://www.spiedigitallibrary.org/terms-of-use 